Matrik: Jurnal Manajemen, Teknik Informatika, dan Rekayasa Komputer

Vol. 20, No. 1, November 2020, pp. 19 26

ISSN: 2476-9843, accredited by Kemenristekdikti, Decree No: 3/E/KPT/2019

DOI: $10.30812 /$ matrik.v20i1.709

\title{
Evaluasi Usability pada Web GIS Pemantauan Kesehatan Hutan Menggunakan Metode System Usability Scale (SUS)
}

Agung Yoga Pangestu, Rahmat Safe'i, Arief Darmawan, Hari Kaskoyo

Universitas Lampung, Indonesia

\section{Article Info}

Article history:

Received, 25 April 2020

Revised, 2 May 2020

Accepted, 2 July 2020

\section{Kata kunci:}

System Usability Scale

Web GIS

Evaluasi

Simantan

Pemantauan Kesehatan Hutan

\section{Keywords:}

System Usability Scale Web GIS

Evaluation

Simantan

Forest Health Monitoring

\begin{abstract}
ABSTRAK
Pemantauan kesehatan hutan menjadi salah satu kriteria pada pengelolaan hutan yang lestari. Saat ini, data dan informasi mengenai persebaran lokasi dan hasil pemantauan kesehatan hutan dapat diketahui melalui Web GIS (Gheographic Information System) Pemantauan Kesehatan Hutan (Web GIS Simantan) yang masih dalam tahap pengembangan. Oleh karena itu, perlu dilakukan evaluasi untuk mengetahui kegunaaanya (usability). Penelitian ini dilakukan untuk mengetahui usability dari Web GIS Simantan menggunakan metode System Usability Scale (SUS) yang didalamnya terdiri dari 5 pertanyaan negatif dan 5 pertanyaan positif. Sebanyak 15 responden dilibatkan dalam penelitian ini yang berasal dari $33.33 \%$ atau setara 5 orang pegawai Balai Pengelolaan Daerah Aliran Sungai dan Hutan Lindung (BPDASHL) Way Seputih Way Sekampung, 33.33\% pegawai Taman Hutan Raya (Tahura) Wan Abdul Rachman dan 33.33\% Mahasiswa Kehutanan Unila. Hasil penelitian menunjukkan bahwa Web GIS Simantan memiliki nilai akhir System Usability Scale (SUS) sebesar 70,50. Dengan demikian, Web GIS Simantan memiliki acceptability ranges dengan kategori marginal high, grade scale dengan kategori D dan adjective rating dengan kategori good.
\end{abstract}

\section{ABSTRACT}

Forest health monitoring is one of the criteria for sustainable forest management. At present, data and information on the distribution of locations and results of forest health monitoring can be identified through the Web GIS Forest Health Monitoring (Web GIS Simantan) which is still under development. Therefore, it needs to be evaluated to find out its usability. This research was conducted to determine the usability of the Simantan Web GIS using the System Usability Scale (SUS) method which consists of 5 negative questions and 5 positive questions. A total of 15 respondents were involved in this study from 33.33\% or the equivalent of 5 employees of the Way Seputih Way Sekampung Watershed Management Center and 33.33\% employees of Wan Abdul Rachman Forest Park and 33.33\% Forestry Students Unila. The results showed that Simantan Web GIS has a final value of the System Usability Scale (SUS) of 70.50. Thus, Simantan Web GIS has acceptability ranges with marginal high category, grade scale with $D$ category and adjective rating with good category.

This is an open access article under the CC BY-SA license.

\section{Penulis Korespondensi:}

Agung Yoga Pangestu,

Program Studi Kehutanan,

Universitas Lampung.

Email: agungyoga.pangestu@gmail.com 


\section{PENDAHULUAN}

Saat ini salah satu indikator pengelolaan hutan yang lestari adalah kesehatan hutan [1] , [2] . Tercapainya kelestarian hutan diantaranya ditandai dengan hutan dapat menopang kehidupan manusia dan lingkungannya dengan kata lain hutan yang lestari adalah hutan yang mampu memfungsikan seluruh fungsinya [3]. Kesehatan hutan dipantau secara periodik (time series data) dengan tujuan untuk menganalisis kondisi tegakan di masa sekarang dan masa akan datang yang dilakukan secara sistematis pada plot permanen [4]. Pemantauan kesehatan hutan akan menghasilkan status kesehatan hutan yang meliputi persen hidup tanaman, organisme penyebab kerusakan, gejala serangan, intensitas serangan, tingkat keparahan kerusakan, penyebaran serangan dan faktor-faktor yang berpengaruh []ㅡ. Manfaat dari pemantauan kesehatan hutan adalah sebagai alat untuk mengetahui status, perubahan, dan kecenderungan kondisi suatu hutan serta memberikan rekomendasi pada para pengelola hutan dalam pengambilan keputusan berdasarkan data-data yang ada [్].

Data-data mengenai hasil pemantauan kondisi kesehatan hutan (status, perubahan, dan kecenderungan yang terjadi) dipetakan dan dikumpulkan dalam satu database secara menyeluruh menggunakan Web GIS pemantauan kesehatan hutan (Web GIS Simantan). Web GIS Simantan merupakan Sistem Informasi Geografis berbasis Web atau Web GIS yang dapat diakses oleh semua orang sehingga mempermudah dalam memperoleh informasi terkait lokasi dan hasil pemantauan kesehatan hutan.

Web GIS adalah aplikasi GIS yang tersedia melalui web umum [6]. Pengembangan GIS berbasis web adalah teknologi baru di negara-negara berkembang [7]. Web GIS dibuat untuk berbagi dan memperbarui sinkronisasi data serta menyediakannya secara online dengan ditampilkan dalam bentuk peta tematik, yang juga dapat berfungsi untuk membuat solusi dalam pemetaan dan pemantauan perubahan sumber daya alam []ㅡ. Web GIS disebut juga sebagai online GIS, web based GIS, internet mapping atau distributed GIS. Web GIS terdiri dari beberapa domain fungsional utama, yang digeneralisasi berdasarkan platform komunikasi, lingkungan komputasi internet, GIS dan fungsi manajemen data [9]

Penelitian ini menjadikan Web GIS Simantan sebagai objek penelitian yang diharapkan dapat diketahui kekurangan dari Web GIS Simantan tersebut. Web GIS Simantan ini dapat memberikan informasi terkait status, perubahan, dan kecenderungan yang terjadi. Kondisi kesehatan hutan yang sangat penting dalam upaya pengendalian tingkatan rusaknya suatu hutan agar tetap di bawah ambang ekonomi yang masih dapat diterima, sehingga dapat terjaminnya keamanan investasi, konservasi, lindung, dan produksi serta berbagai tipe maupun fungsi hutan lain dapat terwujud [10].

Web GIS Simantan dirancang dengan tujuan untuk mempermudah pemantauan kondisi kesehatan hutan. Hingga saat ini belum pernah dilakukan evaluasi terkait kegunaannya (usability). Padahal Web GIS Simantan ini sangat penting dalam upaya memberikan informasi yang dapat digunakan untuk menentukan keputusan manajemen pengelolaan hutan. Oleh karena itu, perlu adanya evaluasi terutama pada aspek usability terkait Web GIS Simantan.

Usability sendiri merupakan atribut untuk kualitas yang menentukan apakah antarmuka pengguna dapat dengan mudah digunakan [11]. Usability berhubungan dengan tingkatan sebuah produk pada saat digunakan oleh pengguna agar dapat mencapai tujuan yang spesifik dengan efisien, efektif dan memuaskan, konteks penggunaan sendiri terdiri dari tugas, pengguna, peralatan serta lingkungan yang dapat memengaruhi penggunaan produk pada system kerja [12]. Usability sendiri lebih mempertanyakan seberapa baik pengguna dalam menggunakan sebuah fungsi [13].

Evaluasi terkait kegunaan dari Web GIS Simantan menggunakan metode System Usability Scale (SUS). SUS merupakan sebuah standar kuesioner yang digunakan untuk mengukur kepuasaan pengguna atau user dalam menggunakan sebuah sistem. SUS juga dikenal "quick and dirty" pada pengukuran kepuasan pengguna yang artinya penggunaan kuesioner SUS sangat cepat dan data yang dihasilkan dapat dipercaya [14].

Kuesioner SUS terdiri dari sepuluh pernyataan yang berbeda dengan perbandingan pernyataan positif serta negatif adalah 50\%:50\%. Setiap pernyataan direpresentasikan melalui skala Likert paling sedikit sebanyak lima buah dan paling banyak tujuh buah. Pada penelitian ini digunakan lima buah skala Likert (sesuai dengan standar kuesioner SUS yang sudah ditetapkan) dengan keterangan, 1: Sangat Tidak Setuju, 2: Tidak Setuju, 3: Netral, 4: Setuju, dan 5: Sangat Setuju.

Pengisian kuesioner SUS dilakukan setelah responden menggunakan sistem yang dievaluasi. Beberapa manfaat yang dapat didapatkan ketika menggunakan SUS [14] yaitu (1) mampu mengatur responden karena penggunaan skala yang mudah; (2) dapat digunakan dalam jumlah kecil dengan hasil terpercaya; serta (3) sah, SUS dapat membedakan dengan efektif sistem yang baik atau tidak untuk digunakan. 
Dengan dilakukannya evaluasi pada Web GIS Simantan menggunakan metode System Usability Scale, diharapkan akan diperoleh gambaran apakah Web GIS Simantan ini memiliki kegunaan yang sesuai untuk memantau kesehatan hutan dan mempermudah apabila kedepannya akan dilakukan perbaikan.

\section{METODE PENELITIAN}

\subsection{Metode Penelitian}

Metode penelitian merupakan salah satu cara yang digunakan dalam suatu penelitian dalam rangka mencapai tujuan penelitian yang didalamnya berisikan rumusan terkait objek atau subjek yang akan diteliti, teknik-teknik pengumpulan data, prosedur pengumpulan dan analisis data berkenaan dengan fokus masalah tertentu. Metode yang digunakan dalam penelitian ini adalah Metode system usability scale (SUS). SUS dapat digunakan dalam melakukan pengujian sebuah teknologi yang independen baik pada perangkat keras, perangkat lunak, website dan bahkan perangkat seluler [14]. SUS juga dikenal sebagai pengukuran kepuasan pengguna yang "quick and dirty" artinya penggunaan kuesioner SUS sangat cepat dan data yang dihasilkan dapat dipercaya.

\subsection{Pengumpulan Data}

Pada penelitian ini kuisioner digunakan untuk mengumpulkan data. kuisioner adalah salah satu cara pengumpulan data dengan memberikan pertanyaan-pertanyaan kepada sejumlah responden. Pada kasus ini, kuisioner digunakan untuk evaluasi kegunaan Web GIS Simantan. Pengumpulan data dilakukan dengan cara memberikan pertanyaan sesuai dengan system usability scale (SUS) kepada responden untuk dijawab.

Kuesioner SUS pada tabel 1 terdiri dari sepuluh pernyataan yang berbeda dengan perbandingan pernyataan positif serta negatif adalah 50\%:50\%. Setiap pernyataan direpresentasikan melalui skala Likert paling sedikit sebanyak lima buah dan paling banyak tujuh buah. Pada penelitian ini digunakan lima buah skala Likert (sesuai dengan standar kuesioner SUS yang sudah ditetapkan) dengan keterangan,1: Sangat Tidak Setuju, 2: Tidak Setuju, 3: Netral, 4: Setuju, dan 5: Sangat Setuju.

Tabel 1. Kuisioner SUS

\begin{tabular}{ll}
\hline No. & \multicolumn{1}{c}{ Pertanyaan } \\
\hline 1 & Saya berpikir akan menggunakan sistem ini lagi (I am thinking of using this system again) \\
2 & Saya merasa sistem ini rumit untuk digunakan (I feel this system is complicated to use) \\
3 & Saya merasa sistem ini mudah digunakan (I feel this system is easy to use) \\
4 & $\begin{array}{l}\text { Saya membutuhkan bantuan dari orang lain atau teknisi dalam menggunakan sistem ini (I need help } \\
\text { from other people or technicians in using this system) }\end{array}$ \\
5 & $\begin{array}{l}\text { Saya merasa fitur-fitur sistem ini berjalan dengan semestinya (I feel that the features of this system } \\
\text { are working properly) }\end{array}$ \\
6 & $\begin{array}{l}\text { Saya merasa ada banyak hal yang tidak konsisten/ tidak serasi pada sistem ini (I feel there are a lot } \\
\text { of things that are inconsistent / incompatible with this system) }\end{array}$ \\
8 & $\begin{array}{l}\text { Saya merasa orang lain akan memahami cara menggunakan sistem ini dengan cepat (I feel that } \\
\text { other people will understand how to use this system quickly) }\end{array}$ \\
9 & $\begin{array}{l}\text { Saya merasa sistem ini membingungkan (I find this system confusing) } \\
\text { Saya merasa tidak ada hambatan dalam menggunakan sistem ini (I feel there are no obstacles in }\end{array}$ \\
10 & $\begin{array}{l}\text { Saya perlu membiasakan diri terlebih dahulu sebelum menggunakan sistem ini (I need to get used } \\
\text { to first before using this system) }\end{array}$
\end{tabular}




\subsection{Analisis Data}

Perhitungan hasil pengujian SUS dilakukan dengan mengikuti beberapa tata aturan yaitu: Skala jawaban responden dikurangi 1 untuk setiap penyataan dengan nomor ganjil. Pernyataan dengan nomor genap maka 5 dikurangi skala jawaban responden. Skala jawaban responden dan dikali 2.5 lalu dijumlahkan. Skor jawaban semua responden dirata-rata. Hasil skor tersebut kemudian disesuaikan dengan penilaian SUS seperti pada gambar 1. Masuk kategori mana hasil pengujian dengan skor rata-rata yang sudah didapat.

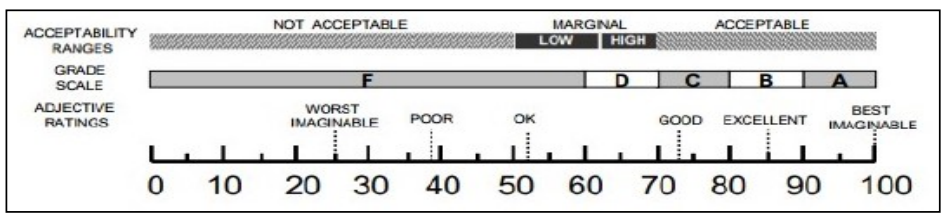

Gambar 1. Penetuan Hasil Penilaian SUS [15]

\section{HASIL DAN ANALISIS}

\subsection{Web GIS Simantan}

Web GIS Simantan adalah sistem yang dibangun untuk memudahkan Penilai kesehatan hutan dalam menyimpan data yang telah diperoleh, membantu pengguna data dalam menemukan lokasi status, perubahan, dan kecenderungan yang terjadi kondisi kesehatan hutan yang diinginkan, serta membantu Stakeholder terkait dalam mendapatkan data mengenai status, perubahan, dan kecenderungan yang terjadi kondisi kesehatan hutan. Web GIS Simantan dapat dilihat pada gambar 2.

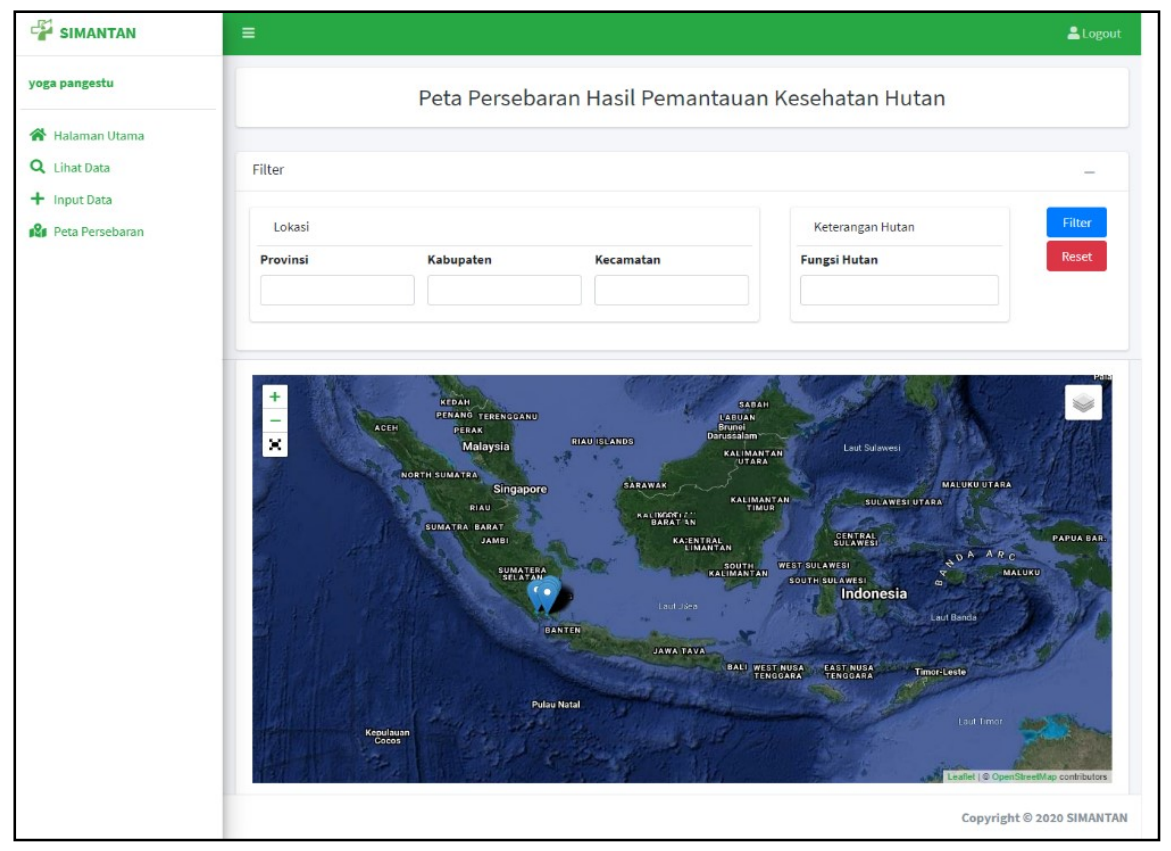

Gambar 2. Web GIS Simantan

Web GIS Simantan ini dibangun dengan menggunakan bahasa pemrograman HTML5, CSS (menggunakan kerangka kerja bootstrap 4), dan Javascript sebagai bahasa pemrograman client side yang berjalan pada sisi client atau browser, PHP (Hypertext PreProcessor) sebagai bahasa pemrograman server side yang berjalan pada sisi server, serta menggunakan PostgreSQL sebagai sistem manajemen basis data.

Dalam pengembangannya kode program ditulis menggunakan text editor sublime. Laptop Acer E5-553G114Q sebagai alat bantu dalam mengembangkan aplikasi ini, serta Windows 10 sebagai sistem operasi untuk menjalankan berbagai aplikasi yang dibutuhkan untuk mengembangkan sistem. XAMPP digunakan dalam mengembangkan sistem ini sebagai perangkat lunak dalam menjalankan web server Apache dimana bahasa pemrograman PHP berjalan didalamnya. Penulis juga menggunakan Mozilla Firefox sebagai browser untuk melakukan pengujian responsivitas antarmuka serta fungsi pada website. 
Web GIS Simantan ini dibangun berdasarkan rancangan sistem, desain antarmuka, dan desain struktur basis data yang telah disetujui sebelumnya. Web GIS Simantan merupakan sebuah sistem yang bertujuan untuk memudahkan pengguna dalam melaporkan data kesehatan hutan. Pengguna dapat mengakses sistem ini untuk menginputkan data kesehatan hutan dan data tersebut dapat dilihat oleh pengguna data.

Hasil dari pelaporan data status kesehatan hutan divisualisasikan dalam bentuk peta persebaran ataupun dalam bentuk tabel data pada. Sedangkan untuk perubahan data divisualisaikan dalam bentuk grafik. Data yang ada akan digolongkan berdasarkan fungsi hutan yang diembannya dan lokasi yang terdapat pada gambar 3 .

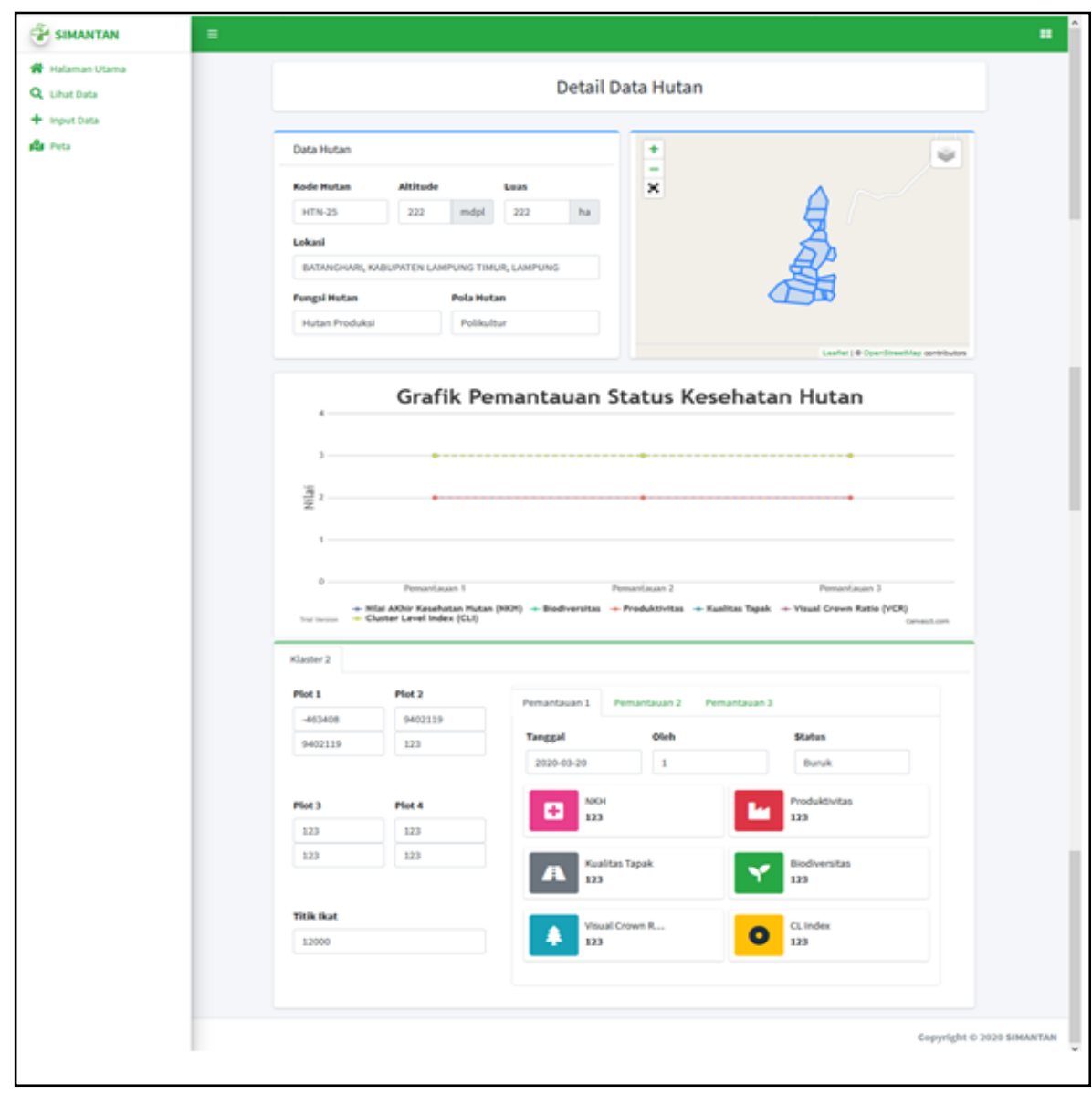

Gambar 3. Detail data kesehatan hutan

Sistem ini dibangun dan dikembangkan menyesuaikan dengan kebutuhan dari pengguna data dan stakeholder sehingga sistem ini dapat digunakan, dan diharapkan dapat membantu dalam pemantauan kesehatan hutan serta menampilkan informasi pemantauan kesehatan hutan dalam bentuk tabel dan peta penyebaran.

\subsection{Responden}

Responden yang digunakan dalam penelitian ini sebanyak 15 orang. Karakteristik responden berdasarkan pekerjaannya terdiri dari 33.33\% atau setara 5 orang pegawai Balai Pengelolaan Daerah Aliran Sungai dan Hutan Lindung (BPDASHL) Way Seputih Way Sekampung, 33.33\% pegawai Taman Hutan Raya (Tahura) Wan Abdul Rachman dan 33.33\% Mahasiswa Kehutanan Universitas Lampung terlihat pada gambar 4. 


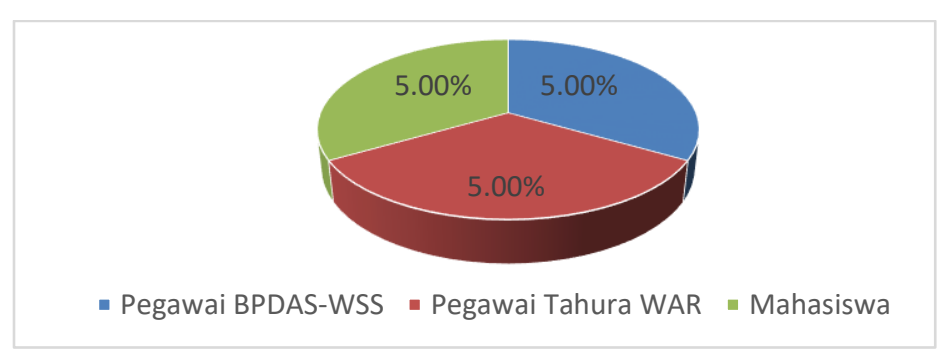

Gambar 4. Persentase pekerjaan responden

Selain berdasarkan pekerjaannya, karakteristik responden berdasarkan jenis kelaminnya terdiri dari $60 \%$ perempuan atau setara 9 orang dan $40 \%$ laki-laki atau setara 6 orang. Sebanyak 15 orang akan menemukan $90 \%$ permasalahan dalam usability [16] pada gambar 5 .

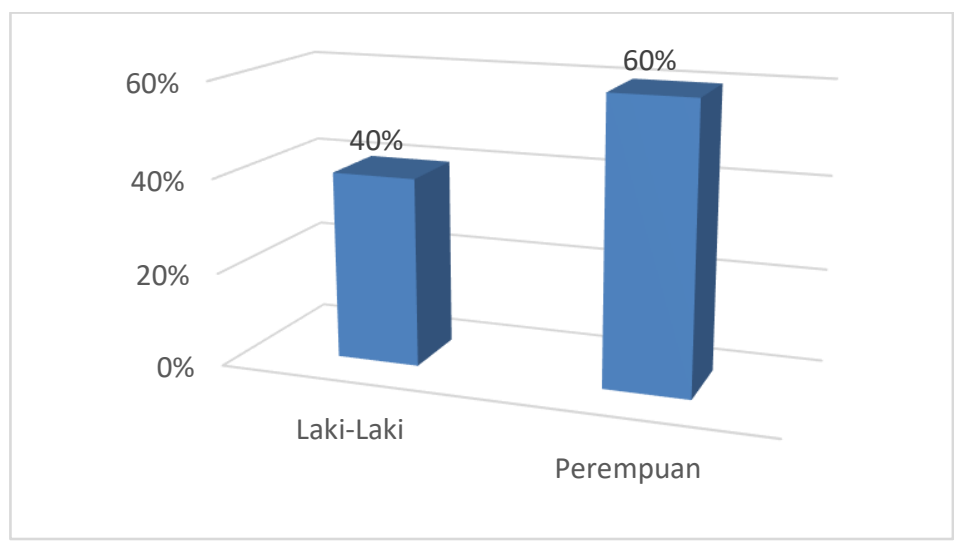

Gambar.5. Persentasi jenis kelamin responden

\subsection{Hasil Penilaian}

Hasil kuisioner yang diperoleh dari 15 responden ditampilkan pada Tabel 2. Setiap item pernyataan bernomor ganjil yaitu 1,3,5,7, dan 9 merupakan pertanyaan positif sedangkan item pertanyaan bernomor genap yaitu 2,4,6,8, dan 10 merupakan pertanyaan negatif. Seluruh item pertanyaan menggunakan lima buah skala Likert (sesuai dengan standar kuesioner SUS) dengan keterangan jika, 1: Sangat Tidak Setuju, 2: Tidak Setuju, 3: Netral, 4: Setuju, dan 5: Sangat Setuju.

Tabel 2. Hasil kuisioner SUS

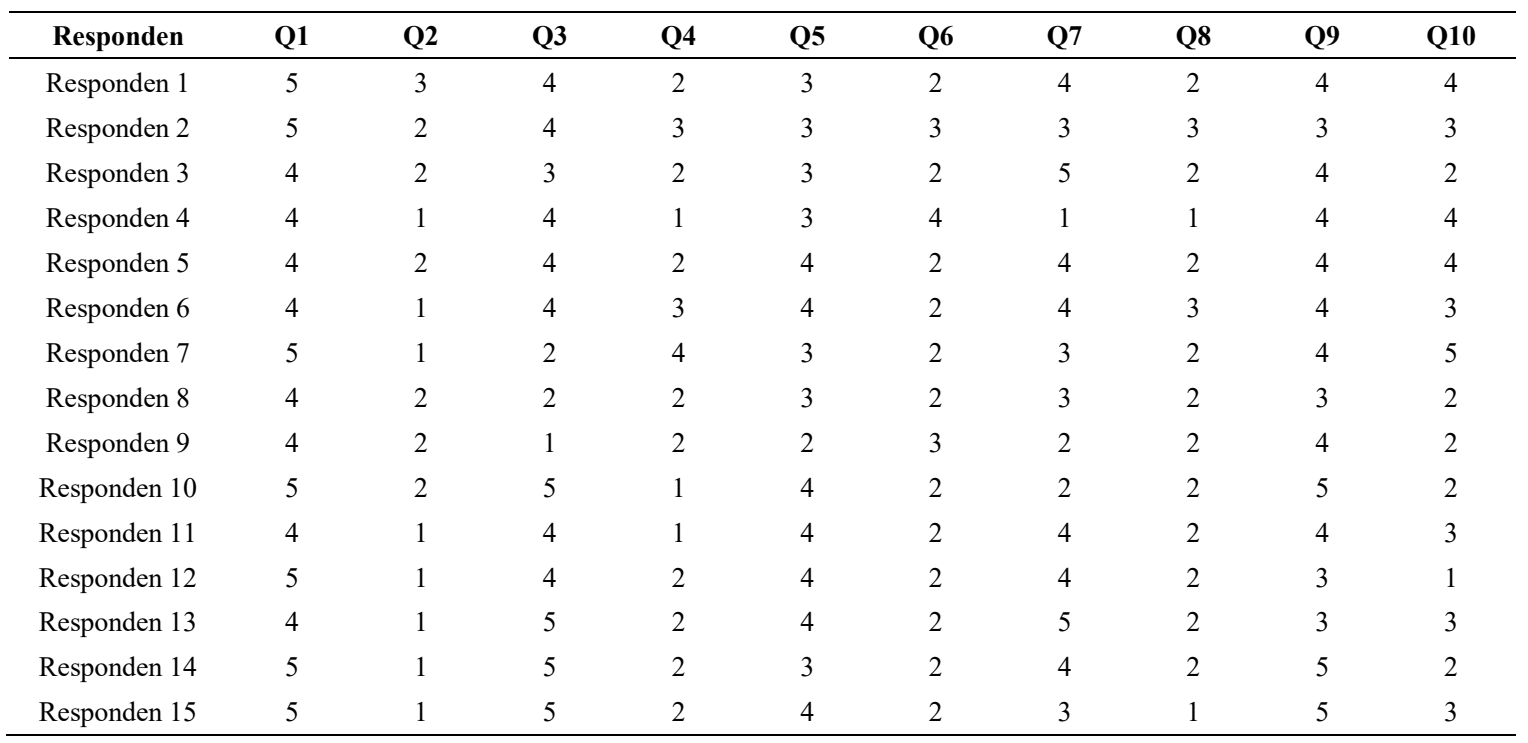


Hasil Kuisinoner pada tabel 2. Merupakan hasil kuisioner yang belum dilakukan perhitungan. Selanjutnya hasil kuisioner tersebut dilakukan perhitungan sesuai System Usability Scale. Setiap penyataan dengan nomor ganjil yaitu $1,3,5,7$, dan 9 , maka skala jawaban responden dikurangi 1 . Setiap pernyataan dengan nomor genap yaitu $2,4,6,8$, dan 10 , maka 5 dikurangi skala jawaban responden. Hasil dari perhitungan jawaban SUS dapat dilihat pada tabel 3 .

Tabel 3. Perhitungan jawaban SUS

\begin{tabular}{lccccccccccc}
\hline \multicolumn{1}{c}{ Responden } & Q1 & Q2 & Q3 & Q4 & Q5 & Q6 & Q7 & Q8 & Q9 & Q10 & Skor SUS \\
\hline Responden 1 & 4 & 2 & 3 & 3 & 2 & 3 & 3 & 3 & 3 & 1 & 27 \\
Responden 2 & 4 & 3 & 3 & 2 & 2 & 2 & 2 & 2 & 2 & 2 & 24 \\
Responden 3 & 3 & 3 & 2 & 3 & 2 & 3 & 4 & 3 & 3 & 3 & 29 \\
Responden 4 & 3 & 4 & 3 & 4 & 2 & 1 & 0 & 4 & 3 & 1 & 25 \\
Responden 5 & 3 & 3 & 3 & 3 & 3 & 3 & 3 & 3 & 3 & 1 & 28 \\
Responden 6 & 3 & 4 & 3 & 2 & 3 & 3 & 3 & 2 & 3 & 2 & 28 \\
Responden 7 & 4 & 4 & 1 & 1 & 2 & 3 & 2 & 3 & 3 & 0 & 23 \\
Responden 8 & 3 & 3 & 1 & 3 & 2 & 3 & 2 & 3 & 2 & 3 & 25 \\
Responden 9 & 3 & 3 & 0 & 3 & 1 & 2 & 1 & 3 & 3 & 3 & 22 \\
Responden 10 & 4 & 3 & 4 & 4 & 3 & 3 & 1 & 3 & 4 & 3 & 32 \\
Responden 11 & 3 & 4 & 3 & 4 & 3 & 3 & 3 & 3 & 3 & 2 & 31 \\
Responden 12 & 4 & 4 & 3 & 3 & 3 & 3 & 3 & 3 & 2 & 4 & 32 \\
Responden 13 & 3 & 4 & 4 & 3 & 3 & 3 & 4 & 3 & 2 & 2 & 31 \\
Responden 14 & 4 & 4 & 4 & 3 & 2 & 3 & 3 & 3 & 4 & 3 & 33 \\
Responden 15 & 4 & 4 & 4 & 3 & 3 & 3 & 2 & 4 & 4 & 2 & 33 \\
\hline
\end{tabular}

Hasil dari tabel 3 belum dilakuan perkalian, sehingga tahap selanjunya adalah mengalikan hasil dari tabel 3 dengan 2,5. Setelah dikalikan, proses selanjutnya adalah melakukan penjumlahan dari hasil perkalian yang dilakukan sebelumnya. Pada tahap akhir, dilakukan penjumlahan hasil perkalian dan dicari rata-ratanya [17]. Hasil perkalian SUS dapat dilihat pada tabel 4.

Tabel 4. Hasil Perkalian SUS

\begin{tabular}{lcc}
\hline \multicolumn{1}{c}{ Responden } & Skor SUS x 2.5 & Jumlah \\
\hline Responden 1 & $27 \times 2.5$ & 68 \\
Responden 2 & $24 \times 2.5$ & 60 \\
Responden 3 & $29 \times 2.5$ & 73 \\
Responden 4 & $25 \times 2.5$ & 63 \\
Responden 5 & $28 \times 2.5$ & 70 \\
Responden 6 & $28 \times 2.5$ & 70 \\
Responden 7 & $23 \times 2.5$ & 58 \\
Responden 8 & $25 \times 2.5$ & 63 \\
Responden 9 & $22 \times 2.5$ & 55 \\
Responden 10 & $32 \times 2.5$ & 80 \\
Responden 11 & $31 \times 2.5$ & 78 \\
Responden 12 & $32 \times 2.5$ & 80 \\
Responden 13 & $31 \times 2.5$ & 78 \\
Responden 14 & $33 \times 2.5$ & 83 \\
Responden 15 & $33 \times 2.5$ & 83 \\
& Nilai rata-rata & 70.50 \\
\hline
\end{tabular}

Hasil dari nilai skor SUS pada tabel 4 dapat diketahui yaitu sebesar 70,50. Rata-rata nilai skor SUS adalah 68. Hal ini berarti nilai skor yang didapatkan Web GIS Simantan berada diatas rata-rata nilai skor SUS secara global. Untuk mengetahui bagaimana perspektif responden, maka hasil dari nilai skor SUS dicocokan dengan Gambar 1. Berdasarkan hasil akhir tersebut, Web GIS Simantan memiliki acceptability ranges dengan kategori marginal high, grade scale dengan kategori D dan adjective rating dengan kategori good. 


\section{KESIMPULAN}

Berdasarkan data yang sudah diperoleh melalui evaluasi System Usability Scale (SUS) dengan 15 responden, Web GIS Simantan memiliki acceptability ranges dengan kategori marginal high, yang artinya responden berpandangan Web GIS Simantan sudah sesuai. Sedangkan untuk hasil grade scale dengan kategori $\mathrm{D}$ dan adjective rating dengan kategori good yang artinya Web GIS Simantan diterima dengan baik oleh responden.

\section{UCAPAN TERIMA KASIH}

Terima kasih Penulis sampaikan kepada Tim pembimbing atas dilibatkannya dalam penelitian terapan tahun 2019 dari DRPM Direktorat Jenderal Penguatan Riset dan Pengembangan Kementerian Ristekdikti. Selain itu, Penulis ucapkan terima kasih kepada BPDASHL Way Seputih Way Sekampung, dan Tahura Wan Abdul Rachman serta pihak-pihak yang telah memberikan dukungan kepada Penulis selama proses penelitian berlangsung sehingga Penulis dapat menyelesaikan penelitian ini dengan baik.

\section{REFERENSI}

[1] E. I. P. Kasno, Noor Farikhah Haneda, Lailan Syaufina, "Pengembangan Metode Penilaian Kesehatan Hutan Lindung dan Hutan Tanaman,” 2019.

[2] R. M. White, J. Young, M. Marzano, and S. Leahy, "Prioritising Stakeholder Engagement Health, Across Spatial, Temporal and Governance Scales, in an Era of Austerity," Forest Ecology and Management, vol. 417, pp. 313-322, May 2018.

[3] R. Safe'i, Hardjanto, Supriyanto, and L. Sundawati, "Pengembangan Metode Penilaian Kesehatan Hutan Rakyat Sengon Falcataria Moluccana ((Miq.) Barneby \& J . W . Grimes)," Jurnal Penelitian Hutan Tanaman, vol. 12, no. 3, pp. 175-187, 2015.

[4] Aristoteles, R. Safe'i, M. Kurnia, D. Pratama, and R. Andrian, "Sistem Informasi Penilaian Kesehatan Hutan Berbasis Web Dengan Framework Laravel," in Prosiding Seminar Hasil Penelitian, 2018, pp. $375-390$.

[5] A. H. S et al., "Evaluasi Kesehatan Pohon di Kawasan Asrama Internasional IPB,” 2019.

[6] M. E. Zerihun, "Web Based GIS for Tourism Development Using Effective Free and Open Source Software Case Study: Gondor Town and Its Surrounding Area, Ethiopia," Journal of Geographic Information System, vol. 9, pp. 47-58, 2017.

[7] G. Ludiema, G. Makokha, and M. M. Ngigi, "Development of a Web-Based Geographic Information System for Mass Land Valuation: A Case Study of Westlands Constituency, Nairobi County," Journal of Geographic Information System, vol. 10, pp. 283-300, 2018.

[8] L. Van Trung and D. M. Tam, "Web GIS Solution for Monitoring the Forest-Cover in the Mekong Delta, Vietnam," Journal of Geographic Information System, vol. 10, pp. 491-502, 2018.

[9] G. M. Krishna, K. N. Ratnam, P. Ravi, and P. Sridhar, "A Holistic Approach for the Development and Implementation of Robust and Cost-Effective Enterprise WebGIS Business Solutions," Journal of Geographic Information System, vol. 7, pp. 478-485, 2015.

[10] R. Safe'i, C. Wulandari, and H. Kaskoyo, "Penilaian Kesehatan Hutan pada Berbagai Tipe Hutan di Provinsi Lampung,” Jurnal Sylva Lestari, vol. 7, pp. 95-109, 2019.

[11] S. Subair and H. AlEisa, "Statistical Models for Web Pages Usability," Journal of Data Analysis and Information Processing, vol. 4, pp. 40-54, 2016.

[12] W. F. Senjaya, T. Witono, and N. Alkhala, "Perancangan dan Evaluasi Usability Aplikasi Pengelolaan Laboratorium Komputer," Journal of Information Systems Engineering and Business Intelligence, vol. 3, pp. 101-106, 2017.

[13] M. Arroofi, A. Kusumah, R. I. Rokhmawati, and F. Amalia, "Evaluasi Usability Pada Website Ecommerce XYZ Dengan Menggunakan Metode Cognitive Walkthrough dan System Usability Scale ( SUS )," vol. 3, pp. 4340-4348, 2019.

[14] U. Ependi, T. B. Kurniawan, and F. Panjaitan, "System Usability Scale vs Heuristic Evaluation: a Review," Simetris: Jurnal Teknik Mesin, Elektro dan Ilmu Komputer, vol. 10, no. 1, pp. 65-74, 2019.

[15] Z. Sharfina and H. B. Santoso, "An Indonesian adaptation of the System Usability Scale (SUS)," International Conference on Advanced Computer Science and Information Systems, vol. 1, pp. 145$148,2017$.

[16] L. Faulkner, "Beyond the five-user assumption: Benefits of increased sample sizes in usability testing," Behavior Research Methods, Instruments, \& Computers, vol. 35, pp. 379-383, 2003.

[17] U. Ependi, A. Putra, and F. Panjaitan, "Evaluasi tingkat kebergunaan aplikasi Administrasi Penduduk menggunakan teknik System Usability Scale," Register: Jurnal Ilmiah Teknologi Sistem Informasi, vol. 5, p. 63, 2019. 